\title{
BIODIVERSITY OF MARINE LIGNICOLOUS FUNGI FROM MANGROVES OF SULU SEA
}

\section{Hanna Hazirah Awaluddin ${ }^{1}$, Norlailatul Asikin Mohamad Nor ${ }^{1}$, Hanzalah Mohamed Nor $^{1}$, Siti Sarah Sharuddin ${ }^{1}$, Ka-Lai Pang ${ }^{2}$, Nuradilla Mohamad-Fauzi ${ }^{3}$, Mohammed Rizman-Idid $^{3}$, Siti Aisyah Alias ${ }^{3 *}$}

\author{
${ }^{1}$ Institute of Biological Sciences, Faculty of Science, University of Malaya, Kuala Lumpur, Malaysia \\ ${ }^{2}$ Institute of Marine Biology and Centre of Excellence for the Oceans, National Taiwan Ocean University, 2 \\ Pei-Ning Road, Keelung 202-24, Taiwan (R.O.C.) \\ ${ }^{3}$ Institute of Ocean and Earth Sciences, University of Malaya, Kuala Lumpur, Malaysia \\ *Corresponding author: saa@um.edu.my
}

\begin{abstract}
Jambongan, Mandidarah and Malawali Islands in the Sulu Sea were chosen for studying marine manglicolous fungi in 2009. Driftwood, prop roots, pneumatophores, subterranean roots, rhizomes, overhanging branches and twigs of mangrove trees were examined for the presence of marine fungi. A total of 173 samples yielded 78 marine manglicolous taxa: 66 Ascomycota, 17 anamorphic morphs and one Basidiomycota. Based on percentage occurrence, the dominating taxa at Jambongan Island were Aniptodera sp. (27.5\%), Sphaerulina oraemaris (24.1\%) and Rhizophila marina (17.2\%); Mandidarah Island were Trichocladium alopallonellum (33.3\%) and Pleospora sp. 1 (13.3\%) and Sphaerulina orae-maris (11.7\%); and Malawali Island were Savoryella lignicola (36.4\%) and Halorosellinia oceanica (20.0\%). Based on Shannon Diversity Index, Jambongan Island harboured the highest diversity of marine manglicolous fungi (3.15), followed by Malawali Island (2.95) and Mandidarah Island (2.87). Sorenson Similarity Index showed that the species composition between the three study sites were dissimilar. Twelve new records of marine fungi were documented in this study which warrants further study in the area.
\end{abstract}

(Keywords: Manglicolous,marine fungi,occurrence,species composition)

\section{INTRODUCTION}

In ecological terms, marine fungi are important in nutrient recycling in the environment, decomposing complex lignocelluloses for nutrition and releasing nutrients for other organisms [1]. Marine fungi have been also recently explored for biotechnological uses in agriculture, medicine and bio-industries [25]. Fungi from marine samples are also useful as microbial resources in the search for new bioactive compounds [6-9].

Since the first report of marine manglicolous fungi by Cribb and Cribb [10], the number of marine fungi has increased dramatically. Kohlmeyer and Kohlmeyer [11] listed 42 species from eight mangrove tree species, while Hyde and Jones [12] documented 90 species from 18 mangrove tree species. A total of 229 species of marine fungi have been recorded in Peninsular Malaysia [13], while Alias and Jones [14] listed 300 taxa from the Malaysian marine ecosystem. Alias et al. [15] reported 33\% of the world's total marine manglicolous fungi have been recorded in Malaysia.

Most of the previous studies on marine fungi in Malaysia had covered the Strait of Malacca [1620] and the South China Sea region [21-23]. The only report of marine fungi in the Sulu Sea was by Pang et al. [23] where 14 species were recorded at
Cape Layak-Layak, Sabah. The collection site was located in the Sulu-Sulawesi marine eco-region that is part of the East Indies Triangle (also known as the Coral Triangle), a relatively small portion of the Indo-Pacific Ocean [24].

The Sulu-Sulawesi marine eco-region has been recognized to be one of the most diverse ecosystems - oceanographically, geologically or topographically [25] - and listed as having CE status, which signifies critical and endangered biomes [26]. Roberts et al. [27] and DeVantier et al. [25] stated that the Sulu-Sulawesi Sea supports megadiversity, with reefs inhabited by more than 500 species of reef-building corals and 2500 species of marine fish, five species of sea turtles and at least 22 species of marine mammals including sperm whales and dugongs. In this study, three islands in the Sulu-Sulawesi eco-region were sampled for marine fungi to investigate their diversity in this biodiversity hotspot.

\section{MATERIALS AND METHODS}

\section{Study sites}

The sampling was undertaken from $23^{\text {rd }}$ June to $27^{\text {th }}$ June 2009 at three chosen continental islands of the Sulu Sea off the northeast coast of Sabah (Figure 1): Jambongan Island (N 6³8’36.58”, E 
117²7'31.98'), Mandidarah Island (N 655'17.75", E $\left.117^{\circ} 19^{\prime} 40.29^{\prime \prime}\right)$ and Malawali Island (N $7^{\circ}$ 3'10.39", E $\left.117^{\circ} 18^{\prime} 10.43^{\prime \prime}\right)$. Jambongan Island is the largest island of all three islands and has the widest mangrove area. Mangroves can be seen along the beach all around Jambongan Island and a large zonation of mangrove can be seen covering the bay from the west to the north of the island. Mandidarah Island is the second largest island, covering an area of $2.5 \mathrm{~km}^{2}$ with formation of sandy and rocky shores and with patches of mangrove stand. Malawali Island is the smallest island with rocky shores constructed mainly from ultrabasic rocks [28]. As silt tends to accumulate between rocks, mangroves are more noticeable on rocky shores. Small patches of mangrove were available and this island is surrounded by coral reef.
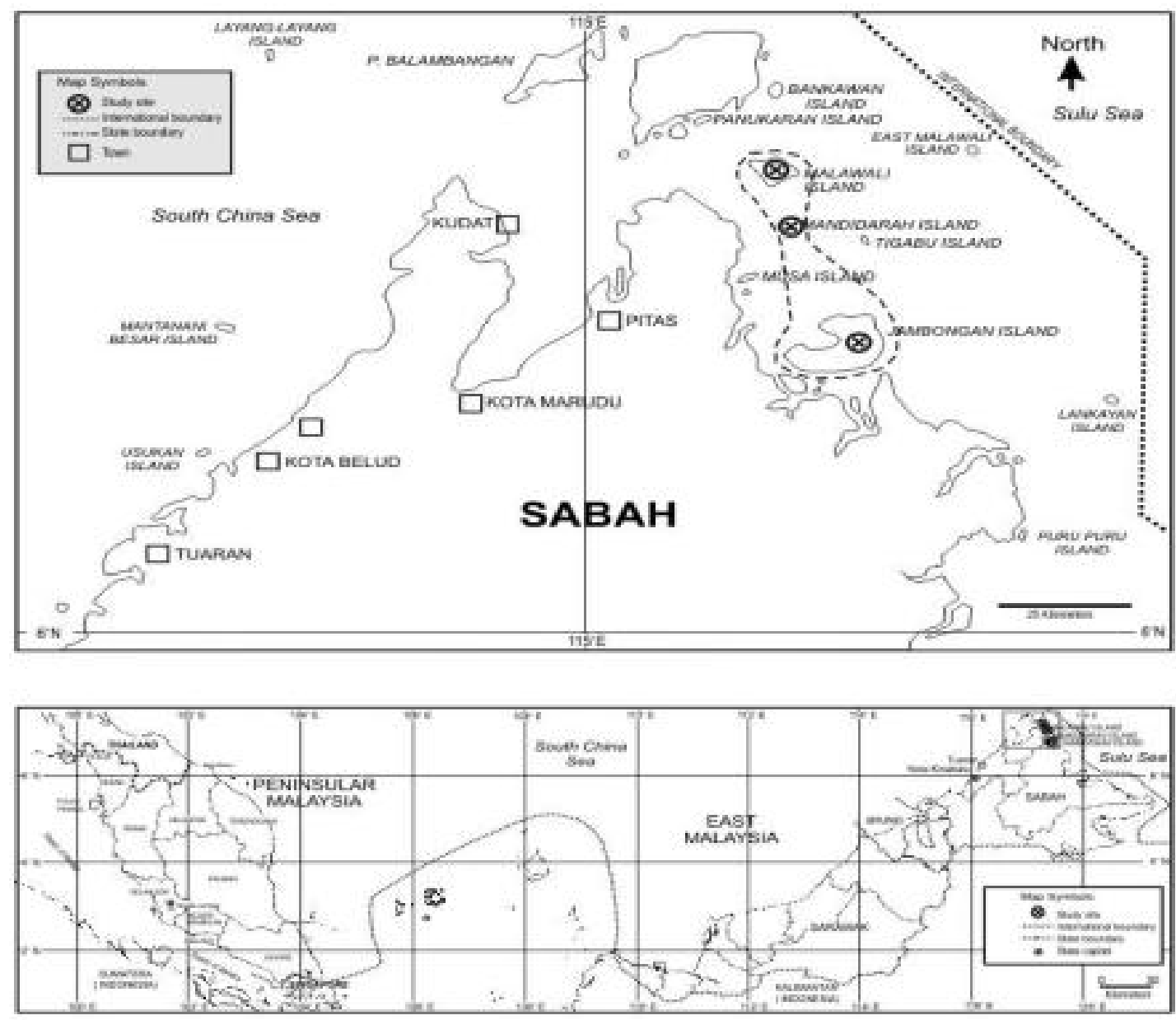

Figure 1.Map of the study sites.

\section{Collection of samples and identification of fungi}

Due to constraints on time and accessibility to some areas of the sites, the sampling strategy was mostly opportunistic. Decaying mangrove driftwood, prop roots, pneumatophores, subterranean roots, rhizomes, overhanging branches and twigs of mangrove trees were randomly collected at the three islands. Samples were then placed in polythene
Ziploc bags. Samples were incubated in a damp chamber to prevent dehydration and examined periodically over a period of 3 months (Figure 2). Slides were prepared for identification on a differential interference contrast (DIC) microscope to record characteristics of the fungi, including morphology of asci, ascospores and ascospore appendages (Figure 3). Fungi were identified using the identification key by Kohlmeyer and Volkmann- 
Kohlmeyer [29] and Sarma and Hyde [30]. Axenic cultures from these isolates were then deposited into the culture collection at the Environmental Microbiology Laboratory at the Institute of Ocean and Earth Sciences, University of Malaya.

\section{Statistical analysis}

Data of the samples collected were analyzed using univariate and multivariate methods:

Univariate methods:

i) Percentage of species occurrence

(Total collection of each species) / (Total number of samples examined) $\times 100$

ii) Percentage of colonization

(Number of samples colonized by fungi) /

(Number of samples examined) $\times 100$

iii) Average number of fungi per sample

(Total number of fungi occurrence) / (Total number of samples examined) $\times 100$

iv) Sorenson's Similarity Index

$$
\mathrm{S}=\frac{2 J}{(A+B)}
$$
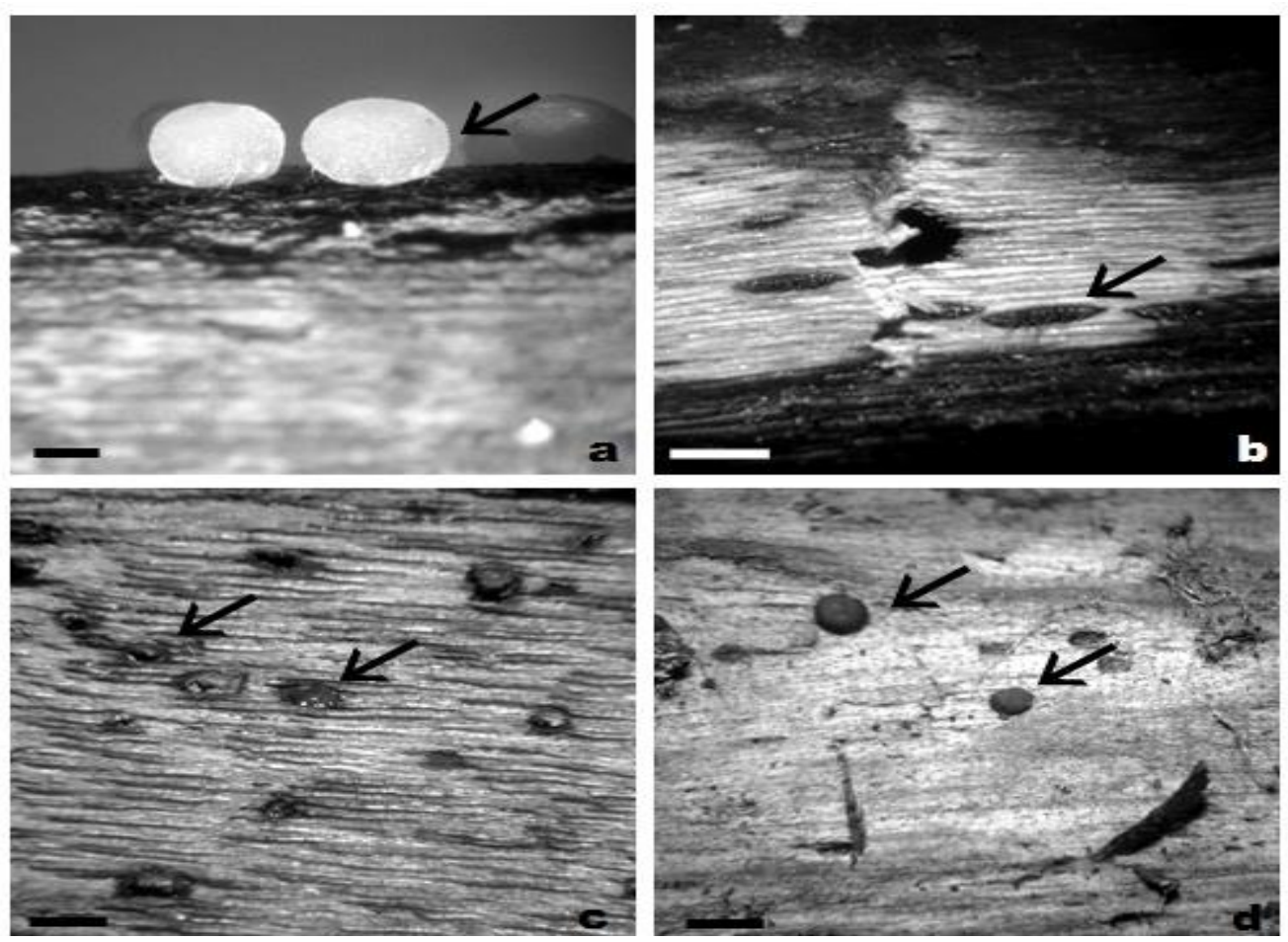

Figure 2. The presence of fruiting body of marine fungi on decaying mangrove wood. (a) Nia vibrissa. (b) Aigialus mangrovei (arrowed). (c) Quintaria lignatilis (arrowed). (d) Dactylospora haliotrepha (arrowed). Scale bars: $\mathrm{a}=2 \mathrm{~mm} ; \mathrm{b}-\mathrm{d}=0.5 \mathrm{~mm}$. 


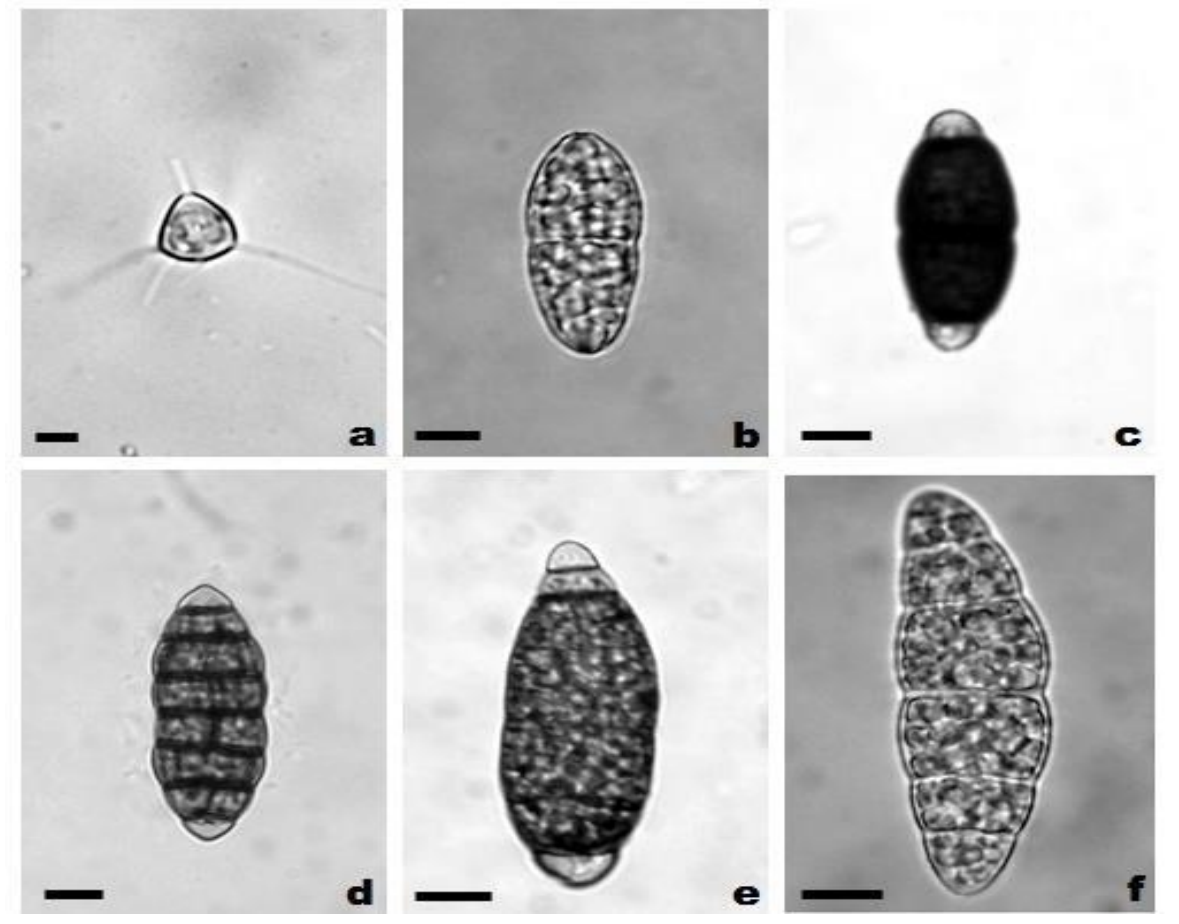

Figure 3: Light micrographs of marine manglicolous fungi in East Malaysia. (a) Nia vibrissa. (b) Kallichroma tethys. (c) Savoryella lignicola. (d) Aigialus mangrovei. (e) Aigialus parvus. (f) Quintaria lignatilis. Scale bars: $\mathrm{a}-\mathrm{c}=5 \mu \mathrm{m} ; \mathrm{d}-\mathrm{f}=10 \mu \mathrm{m}$.

\section{RESULTS}

The marine manglicolous fungi species found at Jambongan, Mandidarah and Malawali Islands of Sabah are listed in Table 1. A total of 173 collected samples yielded 78 taxa of marine fungi representing 60 ascomycetes, 17 anamorphic fungi and one basidiomycete. 39 taxa of marine fungi were recorded for Jambongan Island, followed by 34 taxa from Malawali Island and 33 taxa documented from Mandidarah Island. The highest percentage of colonization was recorded at Malawali Island (91\%), followed by Jambongan Island (86.2\%) and Mandidarah Island (85\%). The average number of fungi per sample at Jambongan Island, Mandidarah Island and Malawali Island was 1.71, 0.67 and 1.47, respectively.

Based on Shannon-Weiner Diversity Index (Table 1), highest diversity was recorded at Jambongan Island (3.15) followed by Malawali Island (2.95) and Mandidarah Island (2.87). Evenness between species from all the study sites was low: Jambongan Island (0.85), Mandidarah Island (0.84) and Malawali Island (0.79).

Species were categorized as very frequent $(>10 \%)$, frequent $(5-10 \%)$ and less frequent $(<5 \%)$ (Table 2$)$.
Very frequent species recorded in Jambongan Island were Aniptodera sp. (27.6\%), Sphaerulina oraemaris and (24.1\%), Rhizophila marina (17.2\%), whereas Trichocladium alopallonellum (33.3\%), Pleospora sp. $1(13.3 \%)$ and Sphaerulina oraemaris and $(11.7 \%)$ were very frequent species encountered in Mandidarah Island. Savoryella lignicola (36.4\%) and Halorosellinia oceanica $(20.0 \%)$ were very frequent species in Malawali Island.

There are 12 new records of marine fungal species from these three islands and another 29 unidentified species in the list that could be new to science. The 12 newly recorded species for Malaysia are Bicrouania maritima, Camarosporium roumegueri, Chaetomastia typhicola, Gnomonia salina, Heleococcum japonense, Leptosphaeria orae-maris, Lophiostoma acrostichi, L. asiana, Oceanitis cincinnatula,Phaeosphaerianeomaritima, Sphaerulina orae-maris and Wettsteinina marina.

Sorenson's Similarity Index (Table 3), between all pairwise comparisons of the sampling sites was recorded between 0.31 to 0.36 . Principal Component Analysis showed that the fungal distribution between study sites were significantly different (Figure 4). 


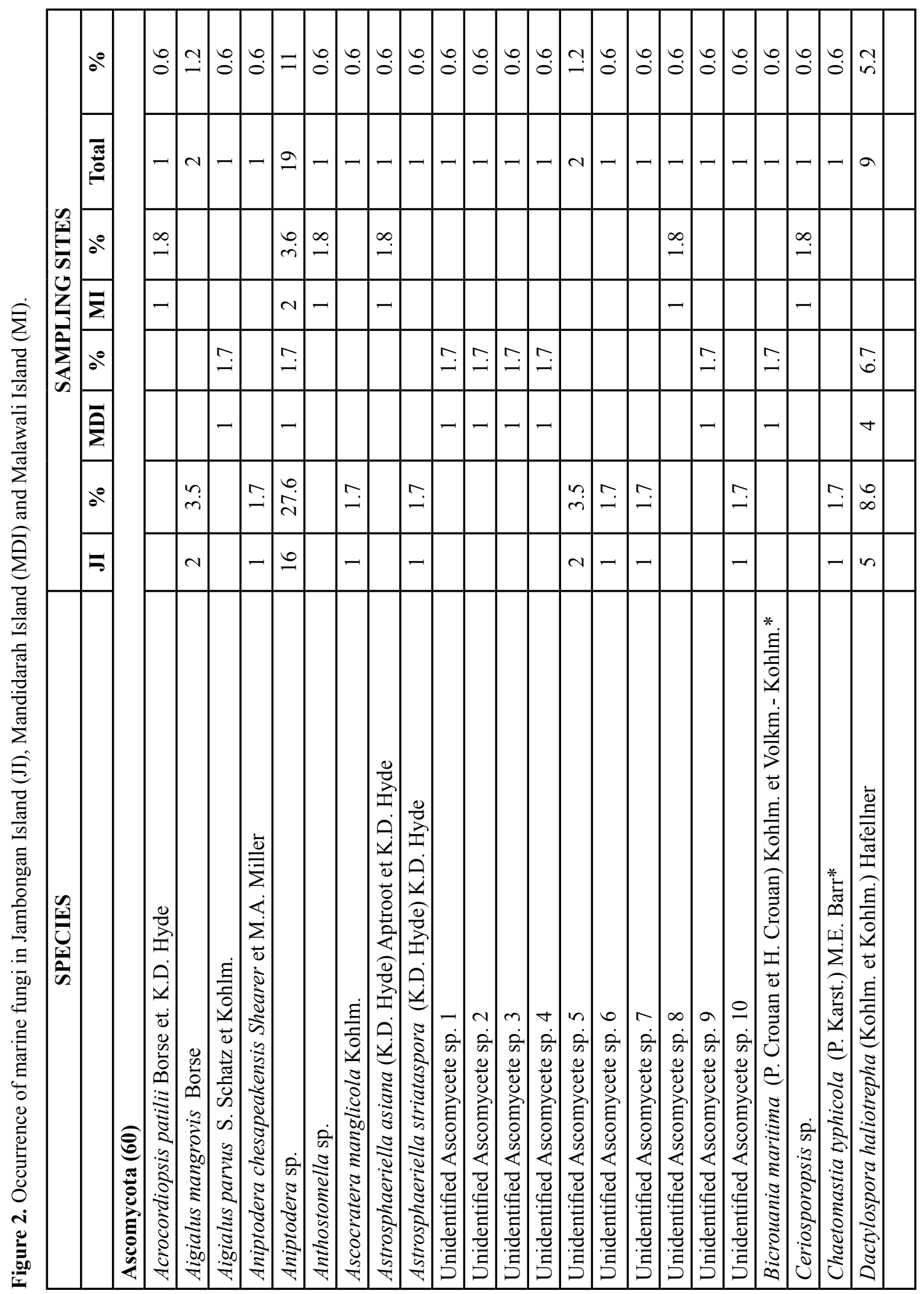




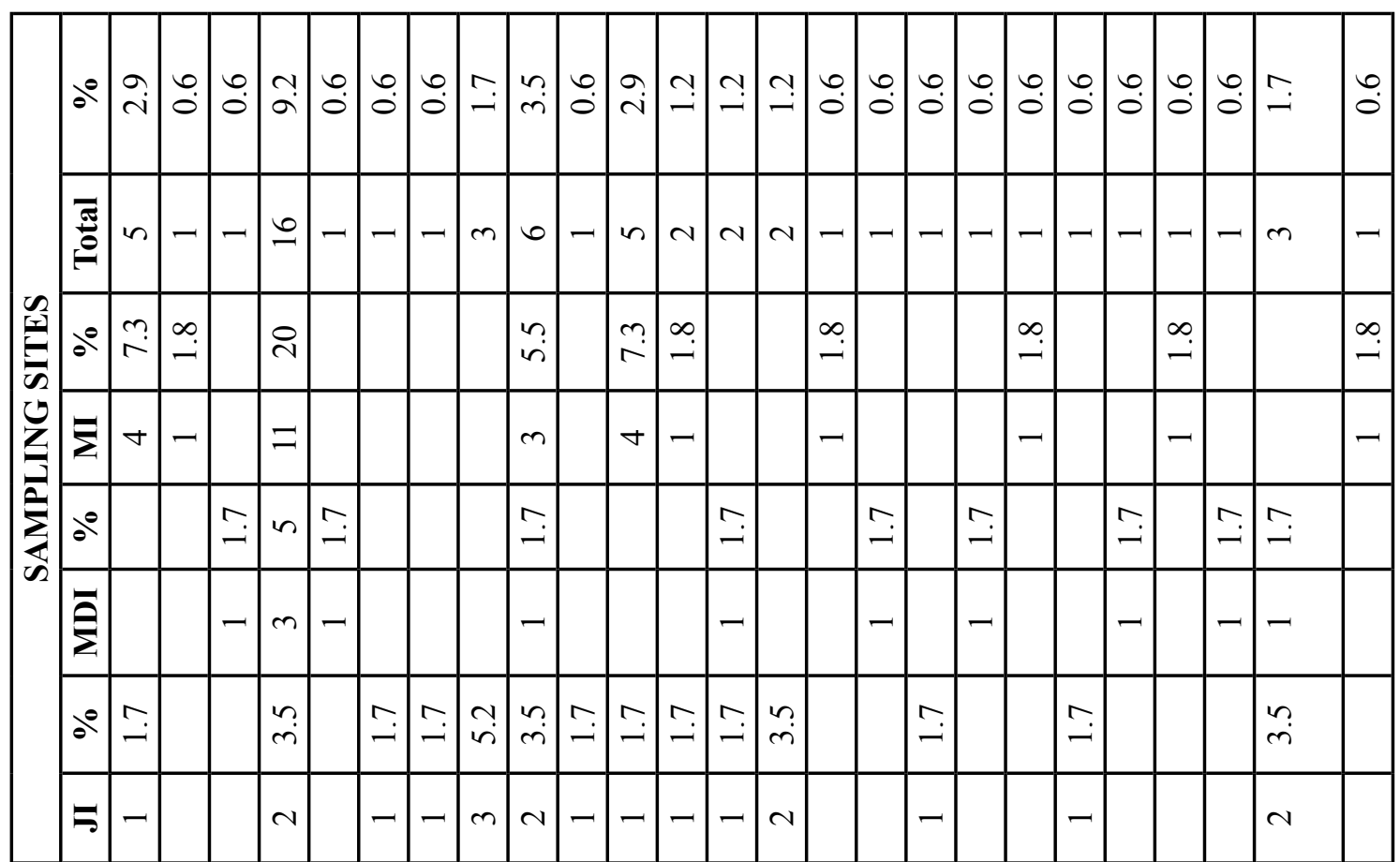

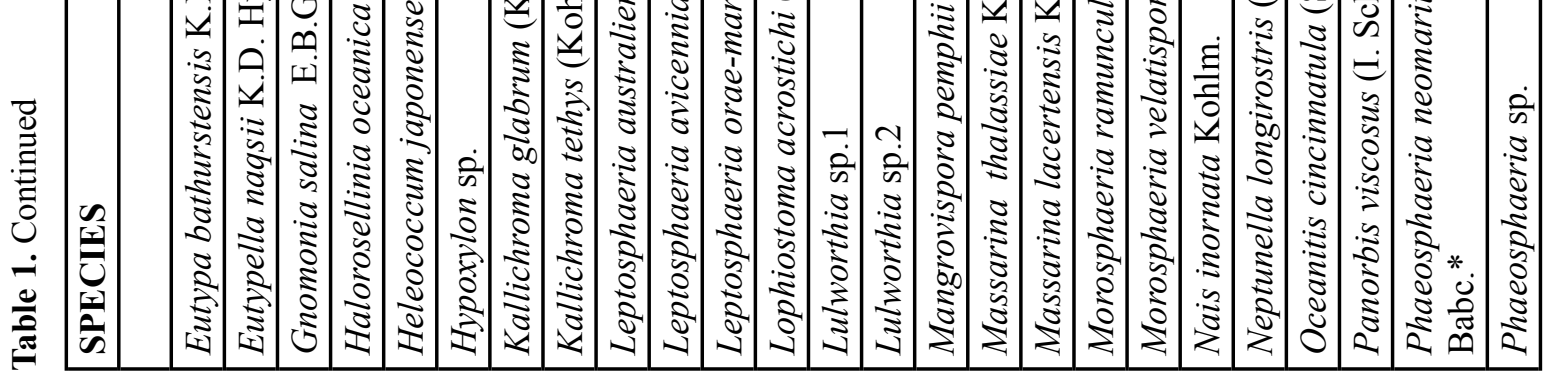




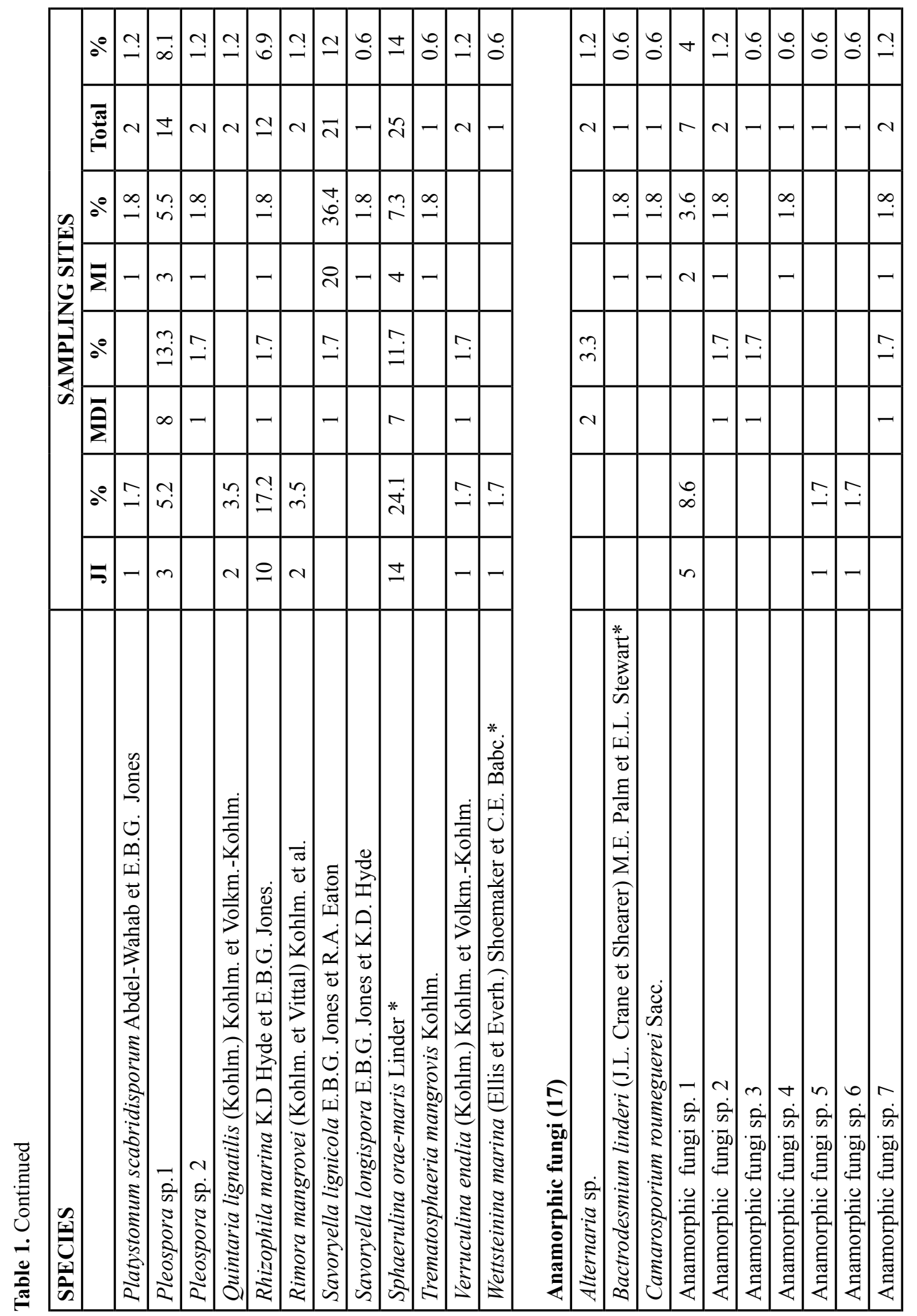




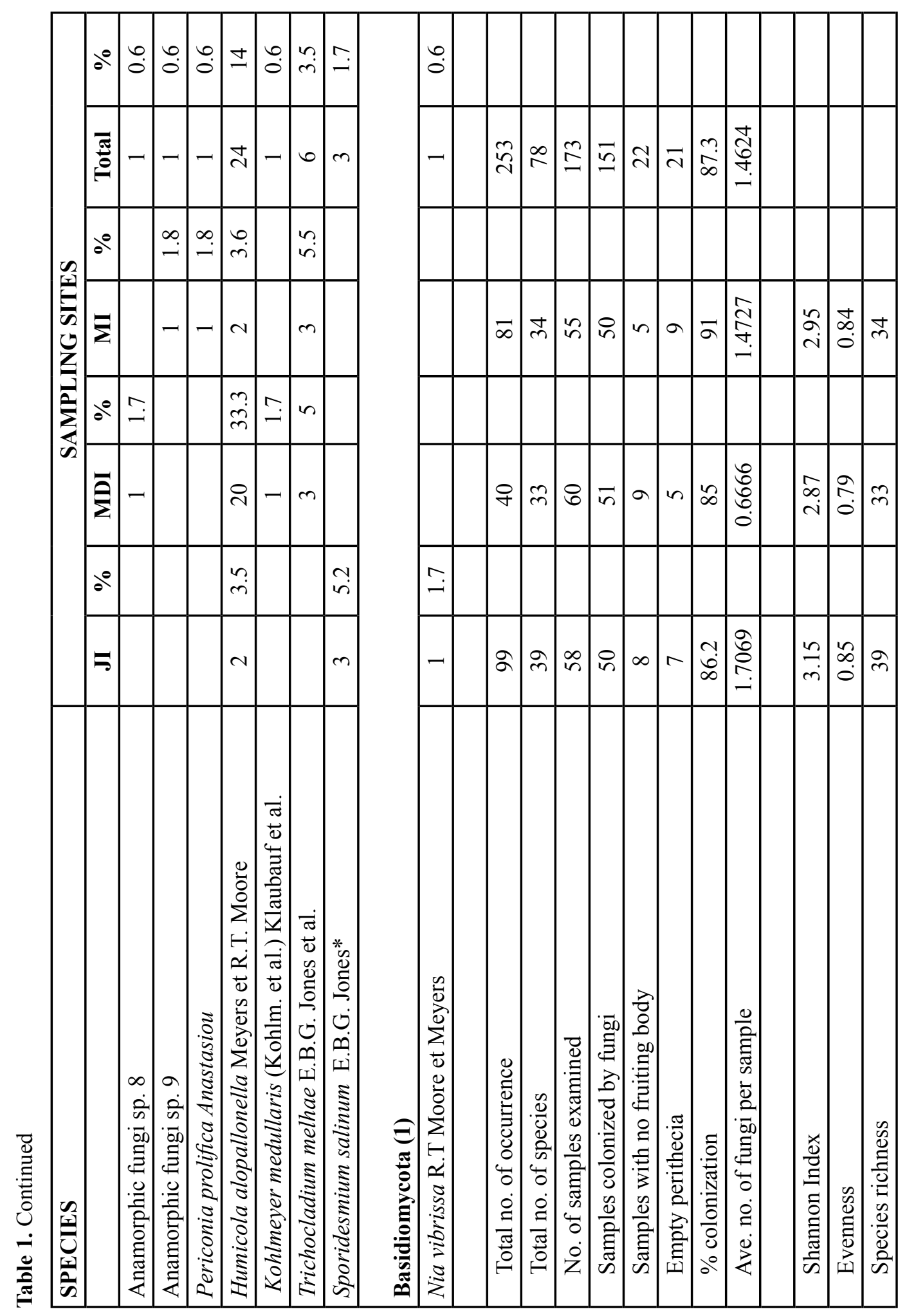

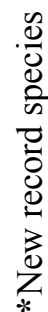


Table 2. Frequent marine manglicolous fungi of the East Malaysian mangroves.

\begin{tabular}{lll}
\hline Location & Very Frequent $\mathbf{( > 1 0 \% )}$ & Frequent $\mathbf{( 5 - 1 0 \% )}$ \\
\hline Jambongan Island & Sphaerulina orae-maris & Kallichroma tethys \\
& Aniptodera sp. & Pleospora sp. 1 \\
& Rhizophila marina & Sporidesmium salinum \\
& & Dactylospora haliotrepha \\
& Anamorphic fungus 1 \\
\hline Mandidarah Island & Humicola alopallonella & Halorosellinia oceanica \\
& Pleospora sp.1 & Trichocladium melhae \\
& Sphaerulina orae-maris & Dactylospora haliotrepha \\
\hline Malawali Island & Haloresellinia oceanica & Leptosphaeria australiensis \\
& Savoryella lignicola & Pleospora sp.1 \\
& Trichocladium melhae \\
& Eutypa bathurstensis \\
& Leptosphaeria orae-maris \\
& & Sphaerulina orae-maris \\
\hline
\end{tabular}

Table 3. Similarity among the species of marine lignicolous fungi from mangrove between study sites.

\begin{tabular}{cccc}
\hline $\begin{array}{c}\text { Pairs of beaches } \\
\text { compared }\end{array}$ & $\begin{array}{c}\text { Number of species from the } \\
\text { beaches compared }\end{array}$ & Common species & $\begin{array}{c}\text { Community coefficient } \\
\text { of Sorenson }\end{array}$ \\
\hline JI-MDI & $39-33$ & 11 & 0.29 \\
MDI-MI & $33-34$ & 12 & 0.35 \\
MI-JI & $34-39$ & 12 & 0.26 \\
\hline
\end{tabular}

(JI: Jambongan Island, MDI: Mandidarah Island and MI: Malawali Island) 


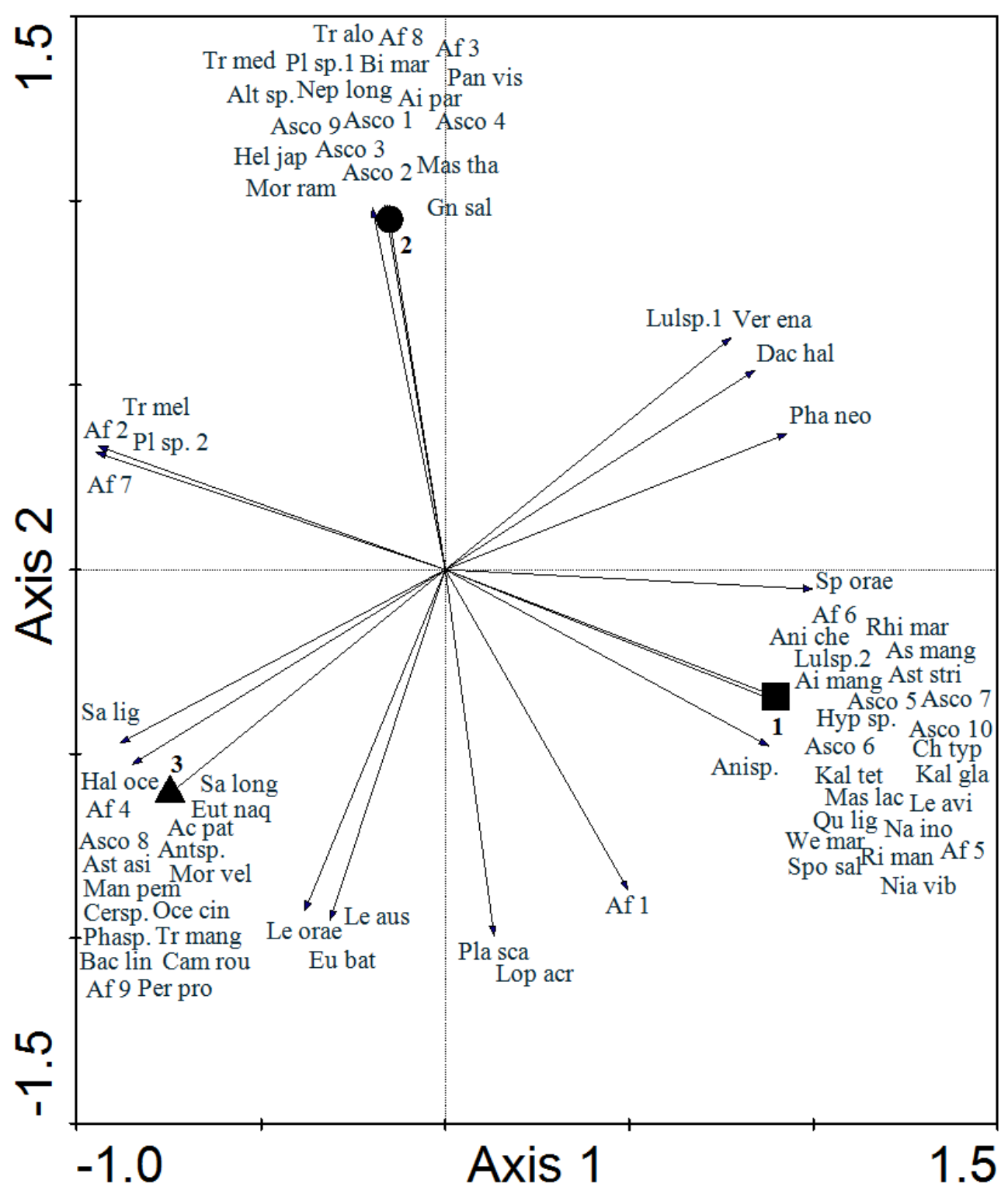

Figure 4. Principal Component Analysis (PCA) of marine fungal species recorded from Jambongan Island, Mandidarah Island and Malawali Island. 


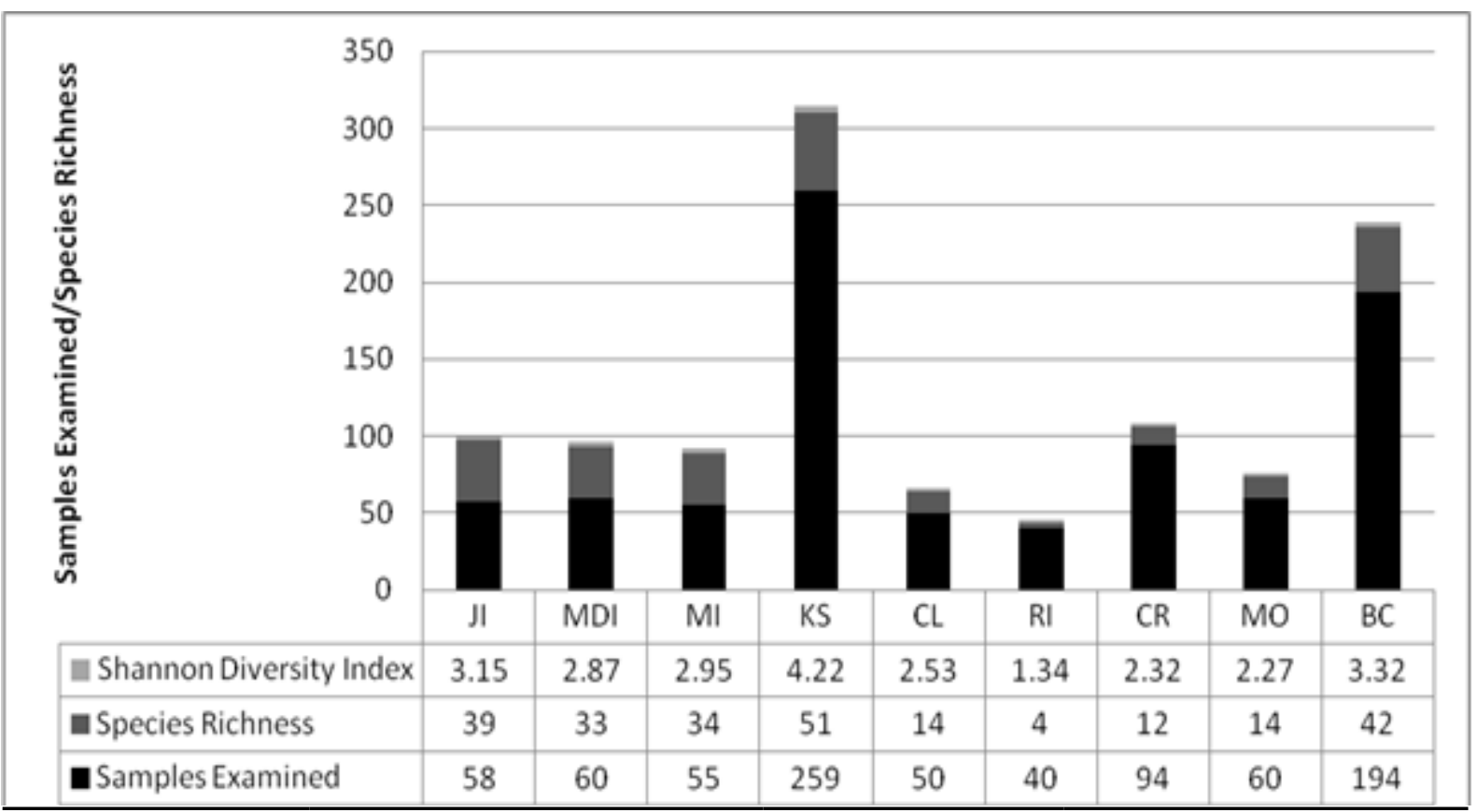

Figure 5. Comparison of species diversity between the present study sites and previous studies in Malaysia (JI: Jambongan Island, MDI: Mandidarah Island, MI: Malawali Island, KS: Kuala Selangor, CL: Cape Layak-Layak, RI: Redang Island, CR: Cape Rachado, MO: Morib, BC: Bachok).

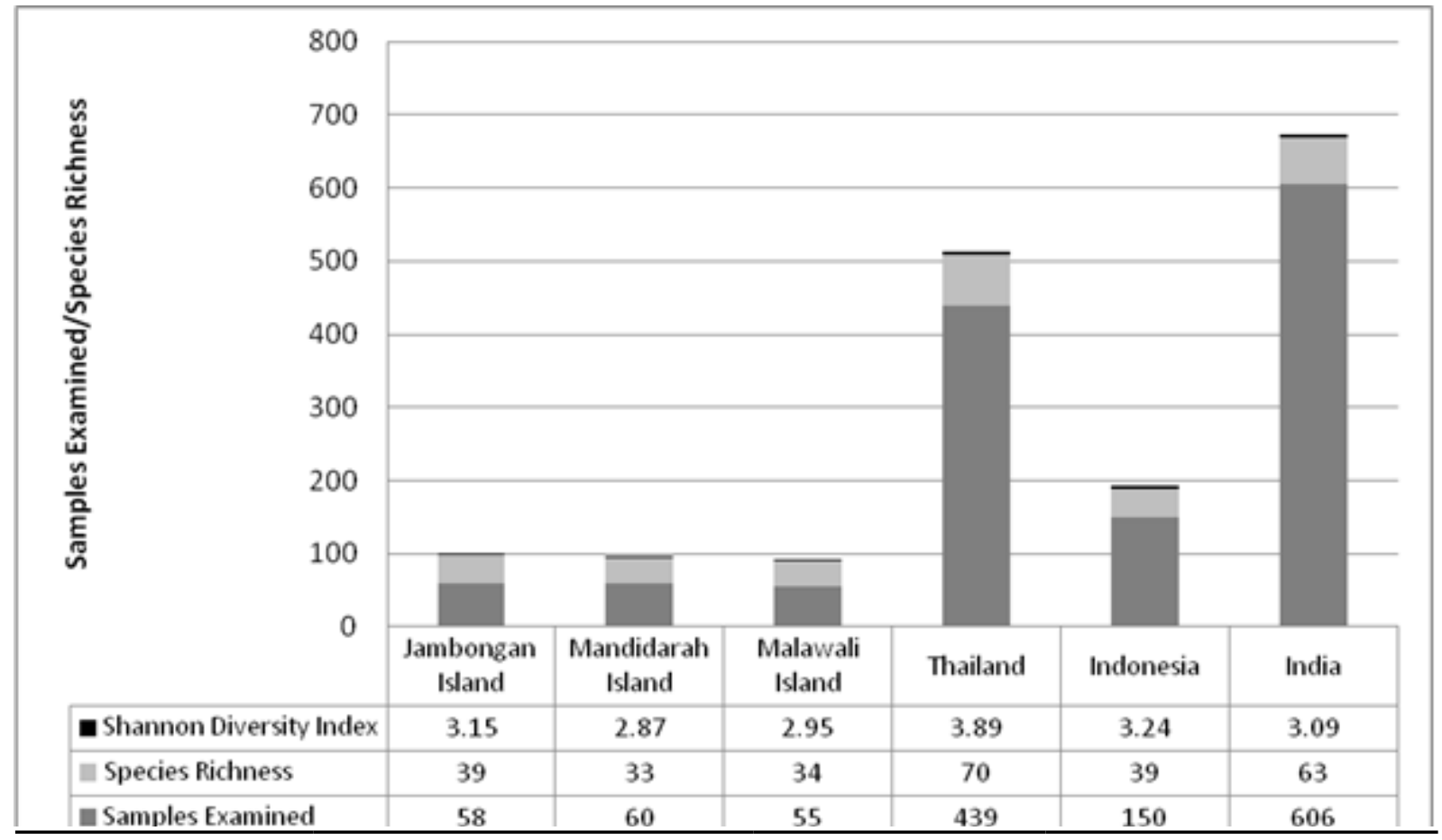

Figure 6. Comparison of species diversity of marine fungi between the present study sites and previous studies in Thailand, Indonesia and India. 


\section{DISCUSSION}

Extensive reports on corals, reef organisms and marine mammals are available from the SuluSulawesi marine eco-region [24, 25, 32], but not on marine fungi. Findings in this study provide integral baseline information on the species of manglicolous marine fungi that can be found on Jambongan Island, Mandidarah Island and Malawali Island in the Sulu Sea. The majority of the marine fungi isolated were ascomycetes (60) and only one basidiomycete, a result concordant with other studies [33]. Species richness and diversity index between the three sites were found to be comparable (between 3339 and 2.87-3.15, respectively). However, very frequent and frequent fungi species recorded in the three study sites (Table 2) were different. The only overlapping fungi that occurred in all the sites were Sphaerulina orae-maris and Pleospora sp. 1. Dactylospora haliotrepha, Halorosellinia oceanica, Savoryella lignicola, Kallichroma tethys, Trichocladium alopallonellum and Verrulina enalia were among the very frequent and frequent species found in the study sites that were consistent with previous studies [14, 15, 23]. This differences in fungal dominance could be due to the composition of mangrove tree species at different sites, bias in the type of substrate (twigs, seedling, branches, root, etc.) collected at different sites or/and the difference in the length of incubation for the different samples $[14,34,35]$.

Outcome from Sorenson's Similarity Index as shown in Table 3 indicated a low level of correlation between the sites. Only five out of the 88 fungal species found reoccurred in all three sites including Aniptodera sp., Leptosphaeria australiensis, Sphaerulina oraemaris and Trichocladium alopallonellum. Further analysis through principal component analysis (PCA) also suggested that the fungal communities among the sites were significantly different. Jones [36] and Hughes [37] stated that location, different mangrove stands, type of mangrove wood and availability of substrates play an important role in the diversity of fungi. While Jambongan Island has a larger mangrove area providing more substrates for colonization, Mandidarah and Malawali Islands have smaller areas of mangrove stand. The higher number of fungi recorded may also be related to higher mangrove diversity at the particular location [14, 38]. Kohlmeyer [39], Jones [36] and KisPapo [40] stated that geographical distribution and the temperature of the sea are key factors that govern the diversity of marine fungi. The present study is the first attempt to study fungal diversity in the Sulu-Sulawesi marine eco-region that is widely known to hold some of the world's highest concentrations of marine biodiversity. Hence, such samples would significantly contribute to future studies on ecosystem functions or adaptive response to climate change.

A comparison on the diversity of marine fungi from this study with previous studies in Malaysia is shown in Figure 5: Kuala Selangor, Bachok, Cape Layak-Layak, Redang Island, Cape Rachado and Morib [22,23]. Diversity index and species richness of the three sites in this study are comparable with Bachok but slightly lower than Kuala Selangor. However, marine fungi in Kuala Selangor have been studied extensively while those in the SuluSulawesi area have not, hence more intensive sampling in the future may result in the discovery of higher diversity. Comparison with data from Cape Layak-Layak, located in mainland of Sabah, 166 $\mathrm{km}$ south-west from the study sites [23] shows that the diversity and species richness there were much lower than in our three study sites. These results may be reflecting the different physical attributes of our study sites in the type, age and density of mangrove stand and the type of substrate collected from the sites $[34,36,38]$. In addition, Kis-Papo [40] and Jones [36] stated that fungal diversity may differ from one mangrove to another within the same region. Overall, there is no doubt that these sites harbour an interesting diversity of fungi and potentially a greater number of species should more studies be done.

Only a few species were observed as dominant in the present study (frequency of occurrence $\geq 5 \%$ ). This may be due to the presence of many rare species of the fungi that occurred only once and was never found again [41]. A larger sample size showed more intermediate species occurring, as seen by a study done in Kuala Selangor that had the largest samples examined (259 samples) and showed less distinction between dominant, intermediate and rare occurring fungi [22]. In conclusion, sample size and the single collection event contributed to the high distinction of dominant and rare fungi of the three study sites. Further collections in the study sites will give better view of the frequency occurrence pattern of dominant and rare fungi in the Sulu-Sulawesi area.

Species diversity comparisons between the study 
sites and countries neighboring Malaysia including Thailand [42], Indonesia [43] and India [44] is shown in Figure 6. The difference in diversity index and the species richness between the present study and India is low but high when compared with Indonesia and Thailand. However, the number of samples examined in this study was much lower, which may suggest a higher diversity when more samples are examined.

This study showed that the diversity of manglicolous marine fungi from Jambongan, Mandidarah and Malawali Islands of the Sulu-Sulawesi region was different from other regions in Malaysia. Many taxa were unidentified and could be new to science. Studying this region is therefore beneficial not only for the inventory of marine fungi of Malaysia, but also as a vital step in understanding some of the main players in the decomposer communities that inhabit this productive biodiverse region. The results obtained from this study only represent a fraction of the diversity of marine mangrove fungi, thus further studies are required to collect a wider range of substrates from a wide geographical area in order to better understand the distribution and composition of marine fungi in the region. The axenic cultures of fungi are important for the study of fungi, be it for genetic conservation and as a basis for studies to investigate adaptive response to climate change. Marine fungi is a good model candidate, since the marine environment and organisms are now under threat from stresses associated with climate change.

\section{ACKNOWLEDGEMENTS}

The authors would like to thank the Ministry of Science, Technology and Innovation (MOSTI) and National Oceanography Directorate Division(NOD) for invitation to participate in Prime Scientific Sailing Expedition 2009 to the Sulu-Sulawesi region. Thank you to the Ministry of Education (MOE) for the Fundamental Research Grant Scheme (FP087/2010A), Higher Institute Centre of Excellence research grant (HICoE) (IOES-2014G) and University of Malaya for the University Malaya Research Grant (RG057/09SUS).

\section{REFERENCES}

1. Jones, EBG and Pang KL (2010) Guest editorial: $11^{\text {th }}$ International Marine and Freshwa- ter Mycology Symposium, Taichung, Taiwan R.O.C., November 2009. Botanica Marina 53: 475-478.

2. Sugiyama J (1998) Relatedness, phylogeny, and evolution of the fungi. Mycoscience 39: 487- 511

3. Pan JH, Jones EBG, She ZG, Pang JY and Lin YC (2008) Review of bioactive compounds from fungi in the South China Sea. Botanica Marina 51: 179-190

4. Debbab A, Aly AH and Proksch P (2012) Endophytes and associated marine derived fungi-ecological and chemical perspectives. Fungal Diversity 57: 45-83.

5. Debbab A, Aly AH and Proksch P (2013) Mangrove derived fungal endophytes-a chemical and biological perception. Fungal Diversity 61: 1-27.

6. Masuma R, Yamaguchi Y, Noumi M, Omura S and Namikoshi M (2001) Effect of seawater concentration on hyphal growth and antimicrobial metabolite production in marine fungi. Mycoscience 42 (5): 455-459

7. Lin $\mathrm{Y}$, Wang J, Wu X, Zhou S, Vrijmoed, LLP and Jones EBG (2002) A Novel Compound Enniatin G from the Mangrove Fungus Halosarpheia sp. (strain \#732)from the South China Sea. Australian Journal of Chemistry 55(3): 225-227

8. Blunt JW, Copp BR, Hu WP, Munro MHG, Northcote PT and Prinsep MR (2008). Marine natural products. Natural Product Reports (NRP) 25: 35-94

9. Ebel R (2012) Natural products from marine-derived fungi: Application of marine fungi. In: Marine Fungi and Fungal-like organisms: Marine and Freshwater Botany (eds. Jones EBG and Pang KL) $1^{\text {st }}$ Edition, pp. 411440.

10. Cribb AB and Cribb JW (1955) Marine fungi from Queensland. I. Papers, University of Queensland, Department of Botany 3: 78-81

11. Kohlmeyer J and Kohlmeyer E (1979) Marine Mycology: The Higher Fungi. Academic Press, 
New York, USA

12. Hyde KD and Jones EBG (1988) Marine mangrove fungi. P.S.Z.N.I: Marine Ecology 9 (1): 15-38

13. Zainudin N, Alias SA and Jones EBG (2007) Frequency of occurrence of marine fungi from Malaysian mangroves. In: Phang SM, Chong VC, Hussin A, Alias SA, Ho SC (eds) Innovations and Technologies in Oceanography for Sustainable Development. pp 269-280

14. Alias SA and Jones EBG (2009) Marine fungi from mangroves of Malaysia. IOES Monograph Series No. 8. Institute of Ocean and Earth Sciences (IOES), University of Malaya, pp 108

15. Alias SA, Zainuddin N and Jones EBG (2010) Biodiversity of marine fungi in Malaysian mangroves. Botanica Marina 53: 545-554

16. Tan TK (1985) Observation on marine fungi in Singapore and Penang. Transaction of British Mycological Society 85: 726-727

17. Jones EBG and Tan TK (1987) Observations on manglicolous fungi from Malaysia. Transactions of the British Mycological society 89: 390-392

18. Tan TK and Leong WF (1992) Lignicolous fungi of tropical mangrove wood. Mycological Research 96: 413-414

19. Alias SA and Jones EBG (2000a) Colonization of mangrove wood by marine fungi at Kuala Selangor mangrove stand, Malaysia. Fungal Diversity 5: 9-12

20. Alias SA and Jones EBG (2000b) Vertical distribution of marine fungi in Rhizophora apiculata at Morib mangrove, Selangor, Malaysia. Mycoscience

21. Jones EBG and Kuthubutheen AJ (1989) Malaysian mangrove fungi. Sydowia 41: 160-169

22. Alias SA, Kuthubutheen AJ and Jones EBG (1995) Frequency of occurrence of fungi on wood in Malaysian mangroves. Hydrobiologia 295: 97-106

23. Pang KL, Sharuddin SS, Alias SA, Nor NAM and Awaluddin HH (2010) Diversity and abundance of lignicolous marine fungi from the east and west coasts of Peninsular Malaysia and Sabah (Borneo Island). Botanica Marina 53: 515-523

24. Briggs JC (2005) The marine East Indies: diversity and speciation. Journal of Biogeography 32: 1517-1522

25. DeVantier L, Alcala A and Wilkinson C (2004) The Sulu-Sulawesi Sea: Environmental and socioeconomic status, future prognosis and ameliorative policy options. Ambio 33(1-2): 88-97

26. Olson DM and Dinerstein E (2002) The global 200: Priority ecoregions for global conservation. Annals of the Missouri Botanical Garden 89: 199-224

27. Roberts CM, Colin JM, Veron JEN, Hawkins JP, Allen GR, McAllister DE, Mittermeier CG and Svhueller FW (2002) Marine biodiversity hotspots and conservation priorities for tropical reefs. Science 295: 1280-1284.

28. Hutchison ES (2005) Geology of North West Borneo: Sarawak, Brunei and Sabah, $1^{\text {st }}$ edn. Elsevier B.V, Amsterdam, Netherlands. Pp 212

29. Kohlmeyer $\mathrm{J}$ and Volkmann-Kohlmeyer, B. (1991) Illustrated key to the filamentous higher marine fungi. Botanica Marina 34: 1-61

30. Sarma VV and Hyde KD (2000) Synoptic key to higher marine fungi. In: Hyde KD, Pointing SB (eds) Marine Mycology:A Practical Approach. Fungal Diversity Press, Hong Kong. pp. 271-307

31. Leps J and Smilauer P (2003) Multivariate Analysis of Ecological Data using CANOCO. United Kingdom: Cambridge University Press

32. Chou LM (1997) Southeast Asia as the global center of marine biodiversity. Tropical Coasts 4: 4-8

33. Jones EBG, Sakayaroj J, Suetrong S, Somrithipol S and Pang KL (2009) Classification of marine Ascomycota, anamorphic taxa and Basidiomycota. Fungal Diversity 35: 1-187.

34. Sarma VV and Hyde KD (2001) A review on 
frequently occurring fungi in mangroves. Fungal Diversity 8: 1-34

35. Shcmidt JP and Shearer CA (2003) A checklist of mangrove-associated fungi, their geographical distribution and known host plants. Mycotaxon 85: 423-477

36. Jones EBG (2000). Marine fungi: some factors influencing biodiversity. Fungal Diversity 4: 53-73

37. Hughes GC (1986) Biogeography of Marine fungi. In: The biology of marine fungi (ed S.T. Moss), Cambridge. Cambridge University Press. Pp 275-296

38. Jones EBG and Alias SA (1997) Biodiversity of mangrove fungi. In: Diversity Tropical Microfungi (ed. K.D. Hyde), Hong Kong University Presss pp. 185-200

39. Kohlmeyer J (1984) Tropical marine fungi. P.S.Z.N.I: Marine Mycology 5: 329-378
40. Kis-Papo T (2005) Marine fungal Communities. Mycology Series. 23: 61-92

41. Ho WH, Hyde KD, Hodgkiss J and Yanna (2001) Fungal communities on submerged wood from streams in Brunei, Hong Kong, and Malaysia. Mycological Research 105(12): 1492-1501

42. Sakayaroj J, Supaphon O, Jones EBG and Phongpaichit S (2011) Diversity of higher marine fungi at Hat Khanom-Mu Ko Thale Tai National Park, Southern Thailand. Songklanakarin Journal of Science and Technology 33: $15-22$

43. Hyde KD (1989) Intertidal mangrove fungi from north Sumatra. Canadian Journal of Botany 67: 3078-3082

44. Chinnaraj S (1993) Higher marine fungi from mangroves of Andaman and Nicobar Islands. Sydowia 45 (1): 109-115 